\title{
PENGARUH PROGRAM TELEVISI DETAK KEPRI DAN OPINI PUBLIK TERHADAP SIKAP PEMILIH DI KOTA BATAM
}

\author{
${ }^{1}$ Partahi Fernando Wilbert Sirait, ${ }^{2}$ Ageng Rara Cindoswari \\ ${ }^{1}$ Mahasiswa Program Studi Ilmu Komunikasi Universitas Putera Batam \\ ${ }^{2}$ Dosen Program Studi Ilmu Komunikasi Universitas Putera Batam \\ Email : Fboelan@gmail.com
}

\begin{abstract}
ABSTRAK
Teknologi dalam perkembangan arus produksi, konsumsi dan distribusi informasi mejadi vital. Urgensi peranan teknologi dalam masifikasi informasi juga digunakan oleh media massa terutama media massa elektronik seperti televisi. Perkembangan media massa elektronik hingga saat ini, juga semakin menjanjikan bagi segala pihak, tidak terlepas para elit politik yang memanfaatkan atau bekerjasama dengan para awak media massa dalam menghadirkan berbagai program. Tidak hanya itu, program pemberitaan juga tak kalah menarik bagi sebagian besar pelaku politik guna memunculkan opini di kalangan masyarakat sendiri. Seperti pada pemilihan Presiden beberapa waktu lalu, peran media massa dan program pemberitaannya berhasil merubah sikap masyarakat terhadap sosok seorang calon Presiden. Permasalahan dan penggunaan media massa elektronik dianggap cukup menarik simpati dari masyarakat, dimana dalam program berita di televisi masyarakat dapat melihat dan mendengar langsung apa yang dilakukan dan diucapkan oleh elit politik tersebut. Dan hal ini juga dapat memunculkan respond an opini di masyarakat.
\end{abstract}

Kata Kunci: program pemberitaan, opini, sikap masyarakat

\section{PENDAHULUAN}

Media dan masyarakat adalah dua bagian yang tidak dapat dipisahkan, karena tumbuh dan berkembang seiring dengan timbulnya kesadaran masyarakat akan pentingnya informasi. Pertumbuhan media massa sangat cepat saat ini yang disertai dengan kebutuhan masyarakat akan informasi yang cepat dan akurat. Salah satunya program di televisi atau media elektronik yang banyak diminati berbagai kalangan usia, menjadikan televisi sebagai sumber informasi dalam kehidupan sehari-hari. Menurut Tabroni (2012:95) melalui bukunya yang berjudul "Media Sebagai Saluran Komunikasi Politik" pada tahun 90-an, kampanye menggunakan media massa seperti televisi sudah dimulai. Namun, apa yang dilakukan media massa, khususnya televisi, saat itu hanyalah memindahkan mimbar ke ruang kaca.

Program berita juga disebut sebaga identitas sebuah stasiun televisi. Setiap stasiun televisi tidak ingin ketinggalan, dan berlomba lomba menayangkan program berita yang kreatif dan menarik perhatian masyarakat. Deddy Iskandar Muda (2003) dalam bukunya 
"Jurnalistik Televisi" bahwa salah satunya berita yang akan mendapat tempat bagi pemirsa adalah berita mengenai bencana dan criminal. Namun, media televisi tidak boleh menayangkan berita berita bersifat kekerasan disertai gambar yang mengerikan. Etika ini dimaksudkan agar pemirsa tidak memiliki rasa takut atau trauma yang amat besar.

Kerangka media menyampaikan pemberitaan-pemberitaan politik kepada khalayak. Penyampaian berita dapat dilakukan dalam berbagai bentuk, antara lain berupa audio, visual maupun audio-visual yang didalamnya terdapat simbol politik dan fakta politik, dan dimuat dalam media cetak maupun media elektonik. Penyampaian berita yang dilakukan oleh media sering kali memunculkan pendapat publik atau disebut sebagai opini publik.

Opini publik atau public opinion ialah sebuah fenomena dalam kehidupan sosial dan politik yang mulai dikenal dan digunakan pada akhir abad ke 18 di Eropa dan di Amerika Serikat. Penggunaan istilah ini berkaitan dengan politik dan komunikasi politik tatkala Alquin menyerukan, "vox populi, vox dei" (suara rakyat adalah suara Tuhan). Arifin (2003:17) menyatakan beberapa definisi opini publik dimana salah satunya Opini Publik adalah pendapat, sikap, perasaan, ramalan, pendirian, dan harapan rata - rata individu kelompok dalam masyarakat, tentang sesuatu hal yang berhubungan dengan kepentingan umum atau persoalan - persoalan sosial. Opini publik ini yang sering muncul di kalangan masyarakat umum maupun ahli politik dapat berupa respon dalam menanggapi isu-isu politik terkait dengan perilaku atau strategi politik salah satu kandidat politik maupun pihak pemerintah dalam mengawasi, mengatur dan mengelola situasi politik di Indonesia.

Dalam kaitannya dengan opini publik, propaganda merupakan salah satu metode penting untuk membentuk opini publik itu sendiri. Sebuah pesan sengaja dihembuskan oleh orang atau kelompok tertentu dengan gencar, sebagai upaya mempengaruhi publik akan sesuatu wacana. Dalam hal ini, mereka yang menjadi propagandis mencoba untuk mengarahkan opini publik untuk mengubah tindakan dan harapan dari target individu. Media massa merupakan media penting dalam propaganda. Karakteristik media massa seperti keberadaan khalayak yang luas, heterogen, dan penyebaran pesan yang cepat serta serentak menjadi alasan kuat banyak pihak akhirnya melirik media massa sebagai alat penyebaran pesan tertentu.

Penelitian ini juga melihat dari beberapa contoh jurnal seperti Jurnal "Peranan Media terhadap Analisis Pemilihan Presiden 2009 di Indonesia" dimana kita mengetahui pada saat itu, media massa gencar melakukan pemberitaan mengenai persaingan sengit antara mantan presiden Republik Indonesia Megawati Soekarno Putrid dan Susilo Bambang Yudhoyono, yang dulunya berpasangan sebagai Presiden dan Wakil Presiden RI. Peranan media massa sendiri yang kerap menyoroti kebijakan yang diambil oleh Presiden Megawati, menjadi salah satu faktor rakyat akhirnya memilih untuk memenangkan Presiden Susilo Bambang Yudhoyono dengan partai politiknya.

Dan juga jurnal "Peranan Televisi Lokal Sebagai Medium Pencitraan Lokalias Daerah". Dimana peneliti dapat melihat sinergisitas antara pemerintah daerah dengan stasiun televisi lokal, yang ingin memperkenalkan kawasan tujuan 
wisata di daerahnya masing masing dengan memberdayakan sumber daya manusia dan skill yang dimiliki para awak media massa tersebut. Hasil tayangan di stasiun televisi lokal ini juga dapat digunakan oleh pihak pemerintah kota setempat, dalam menjadikan referensi bagi para investor asing maupun lokal yang berkunjung ke wilayah tersebut.

Penelitian ini menggunakan teori agenda setting yang diperkenalkan oleh Maxwell E. Mc Comb dan Donald Shaw pada tahun 1972 dalam usaha mengembangkan fungsi gatekeepers dari media massa. Teori Agenda Setting dimulai dengan suatu asumsi bahwa media massa menyaring berita, artikel, atau tulisan yang akan disiarkan. Teori ini mengatakan bahwa media (terutama media berita) tidak selalu berhasil untuk memberitahukan apa yang kita pikirkan melainkan mereka berhasil mengajak kita memikirkan sesuatu. Henry Subiakto dan Rachma Ida dalam bukunya mengenai Komunikasi Politik, Media, dan Demokrasi menjelaskan secara selektif, "gatekeepers" seperti penyunting, redaksi, bahkan wartawan sendiri menentukan mana yang pantas diberitakan dan mana yang harus disembunyikan. Setiap kejadian atau isu diberi bobot tertentu dengan panjang penyajian (ruang dalam surat kabar, waktu pada televisi dan radio) dan cara penonjolan (ukuran judul, letak pada suratkabar, frekuensi penanyangan, posisi dalam surat kabar, posisi dalam jam tayang.

Penelitian ini yang menjadi fokus kajiannya adalah media elektronik, yaitu TV lokal batam yakni Batam TV. Dengan program berita Detak Kepri, yang memuat berbagai unsur mulai dari unsur budaya, politik, ekonomi, sosial, hingga kriminal. Program pemberitaan ini sendiri menjadi salah satu ikon unggulan dari
Batam TV, dan mendapatkan respon yang sangat baik dari para pemirsa yang dapat berinteraksi menanggapi pemberitaan dengan berpartisaipasi dengan memberikan opini mereka dalam segmen interaktif yang selalu ada di setiap harinya.

\section{METODE PENELITIAN}

Penelitian yang di gunakan adalah penelitian kuantitatif. Penelitian kuantitatif adalah jenis penelitian yang menghasilkan penemuan-penemuan yang dapat dicapai dengan menggunakan prosedur-prosedur statistik atau cara-cara lain dari kuantifikasi. Pendekatan kuantitatif memusatkan perhatian pada gejalagejala yang mempunyai karakteristik tertentu didalam kehidupan manusia yang dinamakannya sebagai variabel. Dalam pendekatan kuantitatif hakekat hubungan diantara variabel-variabel dianalisis dengan menggunakan teori yang obyektif. Jenis penelitiannya adalah deskriptif korelasional. Tujuan penelitian ini menggunakan tiga variabel yang terdiri dari, program media elektronik, opini publik serta sikap pemilih. Teknik penelitian yang digunakan pada penelitian ini melalui penyebaran kuesioner terhadap masyarakat yang tinggal di Kecamatan Batam Kota.

Syamsudin (2013:8-9), penelitian kuantitatif merupakan penelitian yang diperoleh dengan mengukur nilai satu atau lebih variabel dalam sampel. Penelitian kuantitatif menggunakan data yang berupa angka dan memakai statistik sebagai alat analisis data. Metode Penelitian survei adalah penelitian yang mengambil yang mengambil sampel dari satu populasi dan menggunakan kuesioner sebagai alat pengumpulan data yang pokok, (Sugiyono, 2013:6). 


\section{Variabel Independen}

Variabel independen adalah variabel yang menyebabkan munculnya variabel lain (Syamsudin, 2013:16). Variabel independen dalam penelitian ini adalah Program "Detak Kepri” serta “Opini Publik".

\section{A. Program Detak Kepri (X1)}

Kita sudah mengetahui mengenai kareteristik suatu peristiwa (fakta dan opini) yang laik menjadi berita, yakni bahwa fakta dan opini tersebut harus mengandung unsur penting dan menarik. Begitu juga dengan pesan lainnya yang menghibur. Tetapi pesan yang akan disampaikan melalui media televisi memerlukan pertimbangan lain agar diterima oleh khalayak sasaran, (Komunikasi Massa: Suatu Pengantar).

\section{Dimensi:}

1. Pemirsa

Dalam setiap bentuk komunikasi, melalui media apapun komunikator akan menyesuaikan pesan dengan latar belakang komunikannya. Namun, untuk komunikasi melalui media elektronik khususnya televisi, factor pemirsa memiliki perhatian lebih.

Indikator : a. kategori anak - anak

b. kategori remaja

c. kategori dewasa dan orang tua

\section{Waktu}

Setelah komunikator mengetahui minat dan kebiasaan tiap kategori pemirsa, langkah selanjutnya adalah menyesuaikan waktu penayangan dengan minat dan kebiasaan pemirsa.

Indikator : a. siaran pagi

b. siaran siang c. siaran malam

\section{Durasi}

Durasi berkaitan dengan waktu, yakni jumlah menit dalam setiap tayangan acara.

Indikator : a. terlalu singkat

b. terlalu lama

\section{Segmentasi}

Fungsi utama televisi menurut khalayak pada umumnya adalah untuk menghibur, selanjutnya adalah informasi. Tetapi tidak berarti fungsi mendidik dan membujuk dapat diabaikan. Fungsi non hiburan dan non informasi harus tetap ada karena sama pentingnya bagi keperluan kedua belah pihak, komunikator dan komunikan.

indikator : a. hard news

b. soft news

c. feature

\section{B. Opini Publik (X2)}

Kata opini diambil dari kata opinion dalam bahasa Inggris berarti pendapat. Demikian juga dengan kata publik yang juga berasal dari kata publik dalam bahasa Inggris, sebaliknya jika dirangkai menjadi frasa public opinion maka kata public diartikan sebagai umum karena public opinion diterjemahkan kedalam bahasa Indonesia menjadi pendapat umum atau opini publik.

\section{Dimensi:}

1. Intensitas

2. Volume (Dimensi)

3. Isi

\section{Variabel Dependen}


Variabel dependen adalah variabel yang muncul karena adanya atau disebabkan oleh variabel independen (Syamsudin, 2013:16). Variabel dependen dalam penelitian ini adalah sikap pemilih.

\section{A. Sikap Pemilih (Y)}

Dimensi: Aspek Konatif

Aspek konatif kepribadian ditandai dengan tingkah laku yang bertujuan dan impuls untuk berbuat. Konasi berupa bereaksi, berusaha, berkemauan, dan berkehendak (chaplin,1995). Menurut Freud konasi merupakan wujud dari kognisi dan afeksi dalam bentuk tingkah laku. Pada perkembangan kepribadiannya, Freud memandang bahwa tahun-tahun permulaan masa kanak-kanak merupakan dasar pembentukan kepribadian. Segala sesuatu yang ada dalam pikirannya ia wujudkan dalam bentuk perilaku yang nyata yang terbagi dalam beberapa fase.

\section{Populasi dan Sampel}

\section{Populasi}

Populasi adalah wilayah generalisasi yang terdiri atas obyek atau subyek yang mempunyai kualitas dan karakteristik tertentu yang ditetapkan oleh peneliti untuk dipelajari dan kemudian ditarik kesimpulannya. (Sugiyono, 2013:80). Pada penelitian ini yang menjadi populasi adalah masyarakat Kecamatan Batam Kota mulai dari usia 16-64 tahun yang berjumlah 108.055 orang.

\section{Teknik Pengambilan Sampel}

Menurut Arikunto (2002) pengambilan sampel dapat dilakukan 10\%, 15\%, 20\% dan $25 \%$ dari jumlah populasi. Pada penelitian ini, peneliti mengambil $10 \%$ dari jumlah populasi, sehingga jumlah sampel pada penelitian adalah 30 orang. Sampel adalah kumpulan dari jumlah dan katakteristik yang ada pada populasi yang sudah ditentukan Menurut Sugiyono (2008:116). Penarikan sampel ditentukan dengan menggunakan rumus dengan tingkat kesalahan 10\% (Hasan, 2002:61).

\section{Jenis Data}

Jenis data yang dipakai dalam penelitian ini adalah kuantitatif. Data kuantitatif adalah data yang diukur dalam suatu skala numerik atau angka (Yusi \& Idris, 2009:102).

\section{Sumber Data}

Pengertian sumber data dalam penelitian adalah subjek darimana data dapat diperoleh (Suharsimi Arikunto, 2006:129). Berdasarkan sumbernya data dibedakan menjadi dua jenis, yaitu:

Data primer

Data primer adalah sumber data yang langsung memberikan data kepada pengumpul data (Sugiyono, 2004:129). Data primer dalam penelitian ini adalah data yang terkait dengan variabel X1, X2 dan Y yang diperoleh dari responden melalui penyebaran kuesioner. Pada penelitian ini instrument data melalui penyebaran kuesioner kepada responden yang dianggap telah memiliki populasi yaitu masyarakat yang tinggal di Kecamatan Batam Kota.

Data sekunder

Data sekunder merupakan sumber yang tidak langsung memberikan data kepada pengumpul data (Sugiyono, 2004:129). Teknik 
pengumpulan data sekunder diperoleh melalui analisa dokumen seperti, company profile perusahaan, notulen rapat, memo rapat, dokumen perjanjian kerjasama dengan instansiinstansi dan foto sebagai dokumen penunjang lainnya.

\section{Teknik Pengumpulan Data}

Pengumpulan data dilakukan dengan cara mengajukan pertanyaan dalam bentuk kuesioner kepada responden yang mengacu pada item atau pertanyaan yang berkaitan dengan penelitian. Data ini yang akan dianalisis sebagai sumber data. Data diperoleh dengan menggunakan cara, sebagai berikut:

Kuesioner

Kuesioner (Angket), sejumlah pernyataan tertulis yang disebarkan kepada responden yaitu penonton yang pernah mengikuti program Detak Kepri di Batam TV untuk mendapatkan informasi.

\subsubsection{Instrumen yang Digunakan}

Instrumen yang digunakan dalam penelitian ini adalah Software SPSS (Statistical Prouct and Service Solution) versi 22 for windows. SPSS adalah sebuah program computer yang digunakan untuk membuat analisis statistika SPSS dipublikasikan oleh SPSS Inc. SPSS (Statistical Package for the Social Sciences atau Paket Statistik untuk Ilmu Sosial).

\section{Alat Pengumpul data}

\section{Kuesioner}

Penelitian ini menggunakan kuesioner atau angket sebagai alat pengumpulan data dan jawaban kuesioner diukur dengan skala likert.
Skala likert digunakan untuk mengukur sikap, pendapat dan persepsi seseorang atau sekelompok tentang kejadian atau gejala sosial (Riduwan \& Sunarto, 2009:20)

\section{Analisis Deskriptif}

Menurut Sugiyono (2004:169), analisis deskriptif adalah statistik yang digunakan untuk menganalisa data dengan cara mendeskripsikan atau menggambarkan data yang telah terkumpul sebagaimana adanya tanpa bermaksud membuat kesimpulan yang berlaku untuk umum atau generalisasi.

\section{Uji Validitas Data}

Uji validitas data digunakan untuk mengukur valid atau tidaknya suatu kuesioner. Suatu kuesioner dikatakan valid jika pertanyaan pada kuesioner mampu untuk mengungkapkan sesuatu yang akan diukur oleh kuesioner tersebut. Pengujian validitas ini menggunakan Pearson product moment correlation yaitu dengan cara menghitung korelasi antara skor masing-masing butir pertanyaan dengan total skor. Jika korelasi antara skor masing-masing butir pertanyaan dengan total skor mempunyai tingkat signifikansi di bawah 0,05 maka butir pertanyaan tersebut dinyatakan valid dan sebaliknya (Ghozali, 2009:49). Alat untuk mengukur validitas data adalah Korelasi Pearson. Rumus yang digunakan untuk menguji validitas data adalah rumus pearson korelation ( Noor, $2011:$ 169).

\section{Uji Reliabilitas Data}

Uji reliabilitas data adalah suatu uji yang dilakukan untuk mengukur suatu kuesioner yang merupakan indikator dari suatu variabel atau konstruk. Suatu kuesioner dikatakan reliabel atau handal jika jawaban seseorang dalam 
kuesioner konsisten atau stabil dari waktu ke waktu. Suatu kuesioner dikatakan reliabel atau handal jika memberikan nilai cronbach alpha di atas 0,6. ( Ghozali, 2009:45).

\section{Uji Asumsi Klasik}

Model regresi dapat disebut sebagai model yang baik jika model tersebut memenuhi beberapa asumsi yang kemudian disebut dengan asumsi klasik. Proses pengujian asumsi klasik dilakukan bersama dengan proses uji regresi sehingga langkah-langkah yang dilakukan dalam pengujian asumsi klasik menggunakan langkah kerja yang sama dengan uji regresi.

\section{Uji Normalitas Data}

Uji Normalitas dilakukan guna mengetahui apakah nilai residu (perbedaan yang ada) yang diteliti memiliki distribusi normal atau tidak normal. Nilai residu yang berdistribusi normal akan membentuk suatu kurva yang kalo digambarkan akan berbentuk lonceng, bellshaped curve. Uji normalitas dapat dilakukan dengan menggunakan Histogram Regression Residual yang sudah distandarkan, analisis $C h i$ Square dan juga menggunakan Nilai Kolmogorov-Smirnov. Kurva nilai Residual terstandarisasi dikatakan normal jika :

1. Nilai Kolmogorov-Smirnov $\mathrm{Z}<$ Ztabel, atau

2. Nilai Probability Sig (2tailed) $>\alpha ; \operatorname{sig}>$ 0,05

\section{Uji Pengaruh}

\section{Uji Regresi Linier Sederhana}

Analisis regresi linier sederhana adalah hubungan secara linear antara satu variabel independen $(\mathrm{X})$ dengan variabel dependen $(\mathrm{Y})$. Analisis ini untuk mengetahui arah hubungan antara variabel independen dengan variabel dependen apakah positif atau negatif dan untuk memprediksi nilai dari variabel dependen apabila nilai variabel independen mengalami kenaikan atau penurunan..Data yang digunakan biasanya berskala interval atau rasio.

\section{Uji T Parsial}

Uji $\mathrm{T}$ Parsial adalah uji signifikansi secara parsial dengan tujuan untuk mengukur secara terpisah dampak yang ditimbulkan oleh masing-masing variabel independen terhadap variabel dependen. (Siregar 2013:410) Cara pengujian dilakukan dengan membandingkan antara hasil t-hitung terhadap t-tabel.

\section{Analisis Determinasi}

Analisis Determinasi digunakan dalam hubungannya untuk mengetahui jumlah atau persentase sumbangan pengaruh 99able99le bebas (able99le dependen) dalam model regresi secara serentak atau bersama-sama memberikan pengaruh terhadap 99able99le tidak bebas (99able99le independen). Analisis dilakukan dengan melihat nilai Koefisien Determinasi (KD). Dalam 99able hasil regresi, KD dapat dilihat dengan melihat nilai $R$ Square $\left(\mathrm{R}^{2}\right)$. Nilai ini digunakan untuk melihat sejauh mana model yang terbentuk dapat menjelaskan kondisi sebenarnya.

\section{HASIL DAN PEMBAHASAN}

Pengaruh Program Televisi Detak Kepri terhadap Sikap Pemilih 
Pengaruh program siaran Detak Kepri terhadap sikap pemilih terbukti dengan signifikan, dimana sumbangan variabel program detak kepri terhadap sikap pemilih adalah $15.92 \%$, sedangkan sisanya 84,08\% dipengaruhi faktor lainnya. Selain itu nilai $\mathrm{T}$ hitung $\geq \mathrm{T}$ table atau $4.425 \geq 1.660$ sehingga tolak Ho, artinya koefisien regresi adalah signifikan sehingga program televisi berpengaruh terhadap sikap pemilih.

\section{Pengaruh Opini Publik Terhadap Sikap Pemilih}

Pengaruh Opini Publik terhadap sikap pemilih terbukti dengan signifikan, dimana sumbangan variabel opini publik terhadap sikap pemilih adalah $18.49 \%$, sedangkan sisanya $81.51 \%$ dipengaruhi faktor lainnya. Selain itu nilai $\mathrm{T}$ hitung $\geq \mathrm{T}$ table atau $4.714 \geq 1.660$ sehingga tolak Ho, artinya koefisien regresi adalah signifikan sehingga opini publik berpengaruh terhadap sikap pemilih.

\section{Pengaruh Program Detak Kepri dan Opini Publik Terhadap Sikap Pemilih}

Pengaruh Program Detak Kepri dan Opini Publik terhadap sikap pemilih terbukti dengan signifikan, dimana sumbangan variabel program detak kepri dan opini publik terhadap sikap pemilih adalah $20,79 \%$, sedangkan sisanya $79,211 \%$ dipengaruhi faktor lainnya. Selain itu nilai $\mathrm{F}$ hitung $\geq \mathrm{F}$ table atau $5,461 \geq 3,09$ sehingga tolak Ho, artinya koefisien regresi adalah signifikan sehingga program detak kepri dan opini publik berpengaruh terhadap sikap pemilih

\section{PENUTUP}

Berdasarkan hasil dari analisis indikator program "Detak Kepri” serta "Opini Publik" yang memperoleh respon paling rendah adalah Intensitas penyajian dengan pernyataan Pemirsa selalu mengikuti program "Detak Kepri" dan "Opini Publik" hingga akhir", hal ini dikarenakan responden hanya mengikuti program "Detak Kepri" serta "Opini Publik" ketika mereka sedang mengamati suatu permasalahan saja. Sementara Indikator sikap penonton yang memperoleh respon paling rendah adalah pernyataan Saya mendapatkan informasi mengenai solusi masalah setelah mengikuti program "Detak Kepri”" dan "Opini Publik", hal ini disebabkan responden belum mampu menguasai dalam mengaplikasikan secara maksimal informasi yang diterima. Bagi pihak perusahaan sebaiknya memperhatikan materi-materi siaran yang akan disajikan, dianjurkan informasinya ringan dan sesuai dengan kebutuhan usia responden, terus melakukan inovasi-inovasi ataupun kreasikreasi yang lebih menarik dalam menyajikan program siaran khususnya program siaran “Detak Kepri” serta “Opini Publik”.

\section{SARAN}

1. Bagi peneliti yang akan melakukan penelitian selanjutnya, disarankan untuk mencari dan membaca referensi lain lebih banyak lagi agar hasil penelitian selanjutnya akan semakin baik serta dapat memperoleh ilmu pengetahuan yang baru.

2. Peneliti yang akan melakukan kajian seperti yang diangkat dalam penelitian ini diharapkan memperhatikan variabel variabel penelitian nya.

3. Hasil penelitian ini diharapkan dapat dijadikan sebagai bahan rujukan bagi peneliti selanjutnya yakni dalam program ilmu komunikasi. 


\section{DAFTAR PUSTAKA}

\section{Sumber Buku:}

Subiakto, Henry dan Ida, Rachmah. (2012). Komunikasi Politik, Media, dan Demokrasi (edisi kedua). Jakarta: Prenamedia Group.

Tabroni, Roni. (2012). Komunikasi Politik Pada Era Multimedia. Bandung: Simbiosa Rekatama Media

Heryanto, Gun Gun dan Rumaru, Shulhan. (2013). Komunikasi Politik, Sebuah Pengantar. Bogor: Penerbit Ghalia Indonesia.

Heryanto, Gun Gun. (2010). Komunikasi Politik di Era Industri Citra. Jakarta: Lasswell Visitama.

Ardianto, Elvirano dan Komala, Lukianti dan Karlina, Siti. (2009). Komunikasi Massa, Suatu Pengantar. Bandung: Simbiosa Rekatama Media.

\section{Sumber Jurnal :}

Ranang Agung Sugihartono (2010). Peranan Televisi Lokal Sebagai Medium Pencitraan Lokalias Daerah. Surabaya (Provinsi Jawa Timut). Jurnal Fakultas Seni Rupa dan Desain ISI Surakarta.

Leo Agustino dan Muhammad Agus, (2009). Peranan Media Terhadap Analisis Pemilihan Presiden 2009 di Indonesia. Jurnal Kajian PolitiK.

Esy Nurtias Tuti, (2012). Opini Pendengar Terhadap Program Acara Dangdut Ponoragan di Radio Duta Nusantara Ponorogo (Studi kasus di Komunitas pendengar Dangdut Ponoragan Kabupaten Ponorogo), Provinsi Jawa Timur. 